\title{
Individual differences in system justification predict power and morality-related needs in advantaged and disadvantaged groups in response to group disparity
}

\author{
Hässler, Tabea ; Shnabel, Nurit ; Ullrich, Johannes ; Arditti-Vogel, Anat ; SimanTov-Nachlieli, Ilanit
}

\begin{abstract}
Guided by the needs-based model, we explored how individual differences in system justification predict group members' needs in response to information about group-based disparities. Across two studies $(\mathrm{N}=819)$, we found that among disadvantaged-group members (LGBTIQ* individuals/women) system justification was negatively related to need for power. Among advantaged-group members ([cis]heterosexuals/men), system justification was negatively related to motivation to restore their ingroup's moral essence (i.e., moral shame and wish that the ingroup would act more morally) but positively related to motivation to restore their ingroup's moral image (i.e., need for positive moral image and expectation that the outgroup should acknowledge the ingroup's morality). These results theoretically extend the needs-based model by offering a more nuanced picture of morality-related needs. Further, they underline the importance of considering individual differences in system justification for understanding advantagedand disadvantaged-group members' responses to social inequality.
\end{abstract}

DOI: https://doi.org/10.1177/1368430218773403

Posted at the Zurich Open Repository and Archive, University of Zurich

ZORA URL: https://doi.org/10.5167/uzh-153537

Journal Article

Accepted Version

Originally published at:

Hässler, Tabea; Shnabel, Nurit; Ullrich, Johannes; Arditti-Vogel, Anat; SimanTov-Nachlieli, Ilanit (2019). Individual differences in system justification predict power and morality-related needs in advantaged and disadvantaged groups in response to group disparity. Group Processes and Intergroup Relations, $22(5): 746-766$.

DOI: https://doi.org/10.1177/1368430218773403 
Individual Differences in System Justification Predict Power and Morality-Related Needs in Advantaged and Disadvantaged Groups in Response to Group Disparity

Tabea Hässler ${ }^{1}$, Nurit Shnabel ${ }^{2}$, Johannes Ullrich ${ }^{1}$, Anat Arditti-Vogel², \& Ilanit

$$
\begin{aligned}
& \text { SimanTov-Nachlieli }{ }^{2} \\
& { }^{1} \text { University of Zurich } \\
& 2 \text { Tel-Aviv University }
\end{aligned}
$$

Version accepted for publication in Group Processes and Intergroup Relations (April 2018) We thank Simone Sebben for his insightful and encouraging comments.

\section{Author Note}

This research received funding from German Israeli Foundation (1119-126.412010) and the European Commission Seventh Framework Programme (PCIG09-GA-2011-293602).

Correspondence concerning this article should be addressed to Tabea Hässler, University of Zurich, Department of Psychology, Binzmuehlestrasse 14/15, 8050 Zurich, Switzerland. E-mail: t.haessler@psychologie.uzh.ch 


\begin{abstract}
Guided by the needs-based model, we explored how individual differences in system justification predict group-members' needs in response to information about group-based disparities. Across two studies $(N=819)$, we found that among disadvantaged-group members (LGBTIQ* individuals/women) system justification was negatively related to need for power. Among advantaged-group members ([cis-]heterosexuals/men), system justification was negatively related to motivation to restore their ingroup's moral essence (i.e., moral shame and wish that the ingroup would act more morally) but positively related to motivation to restore their ingroup's moral image (i.e., need for positive moral image and expectation that the outgroup should acknowledge the ingroup's morality). These results theoretically extend the needs-based model by offering a more nuanced picture of morality-related needs. Further, they underline the importance of considering individual differences in system justification for understanding advantaged- and disadvantaged-group members' responses to social inequality. Keywords: structural inequality; needs-based model; system justification; sexual orientation and gender identity; gender relations
\end{abstract}


Individual Differences in System Justification Predict Power and Morality-Related Needs in Advantaged and Disadvantaged Groups in Response to Group Disparity

Advantaged- and disadvantaged-group members experience divergent psychological needs (Shnabel \& Ullrich, 2013). To illustrate, women and LGBTIQ*1 individuals fought similar fights against male dominance and heteronormativity ${ }^{2}$ (Gebhardt, 2016; Hagai \& Crosby, 2016; Whittier, 2004), pointing to a common need for empowerment. Likewise, the influence of these social movements on society means that at least some men and (cis-)heterosexuals ${ }^{3}$ experience the morally-based need to act for greater social equality.

Besides these differential needs, however, both the advantaged and the disadvantaged are motivated to justify the existing social system. According to system justification theory (Jost \& Banaji, 1994), the perception of the social system as legitimate satisfies basic epistemic, existential, and relational needs. Therefore, people might be motivated "to defend, justify, and bolster aspects of the status quo including existing social, economic, and political institutions and arrangements" (Jost \& van der Toorn, 2012, p. 334).

The goal of the present research, consisting of two studies, was to examine how this motivation to justify the system, which varies across individuals, relates to advantaged- and disadvantaged-group members' experience of needs for restoration of power and moral identity when thinking about group-based disparities. We will now discuss the needs-based

\footnotetext{
${ }^{1}$ LGBTIQ* $^{*}$ Lesbian, gay, bisexual, transgender, intersexual, and questioning people. Although sexual orientation and gender identity/expression are distinct, for the sake of conceptual clarity and brevity we included transgender and intersex people with a heterosexual orientation in the LGBTIQ* group. Thus, the heterosexual group in our study included only heterosexual participants whose gender corresponds to their assigned sex (cis-heterosexuals).

${ }^{2}$ Heteronormativity refers to the dominance of heterosexuality in society (Herz \& Johansson, 2015), and can be understood as "the mundane, everyday ways that heterosexuality is privileged and taken for granted as normal and natural" (Martin, 2009, p. 190); e.g., the term "boyfriend jeans".

${ }^{3}$ Cisgender is a term for people whose gender identity matches the sex that they were assigned at birth. It is the opposite of the term transgender. Transgender people have a gender identity/expression that differs from their assigned sex.
} 
model (Nadler \& Shnabel, 2015) and system justification theory (Jost \& Banaji, 1994) - the theoretical perspectives on which we based our predictions.

\section{The Needs-Based Model and Illegitimacy}

The needs-based model was developed to explain the dynamics between groups involved in conflicts characterized by direct violence (e.g., massacres) and in which the roles of "victims" and "perpetrators" are relatively consensual. For example, when referring to the Holocaust, Jews experienced threat to their sense of power, resulting in a heightened need for empowerment, whereas Germans experienced a threat to their morality, resulting in a heightened need for moral acceptance (Shnabel, Nadler, Ullrich, Dovidio, \& Carmi, 2009). Yet, the model's logic can also be applied to contexts characterized by structural inequality, suggesting that groups within a given society often face distinct threats to their identity. Disadvantaged-group members, who are sometimes the target of subjugation and discrimination and are often stereotyped as passive and incompetent (Fiske, Cuddy, \& Glick, 2007), might experience threat to their identity as agentic social actors. By contrast, advantaged-group members are often blamed for discriminating against the disadvantaged groups (i.e., "stigma reversal"; Killian, 1985) and subjected to stereotypes that portray them as cold and bigoted (Fiske et al., 2007). Advantaged-group members might, therefore, experience threat to their moral identity. These group-specific threats might lead to divergent needs for restoration of morality and power among advantaged- and disadvantaged-group members (respectively).

However, as opposed to contexts of direct violence, contexts characterized by structural inequality are often ambiguous with regard to groups' blame for inequality. Thus, it would be too simplistic to assume that the needs of the advantaged and disadvantaged always correspond to those of perpetrators and victims. Indeed, advantaged-group members are often unaware of their privileges (Pratto \& Stewart, 2012) and both the advantaged and the disadvantaged often believe that they deserve their respective positions (Jost, Banaji, \& 
Nosek, 2004; Jost, Gaucher, \& Stern, 2015; Major, 1994), implying that they might not experience heightened needs for restoration of power and moral image.

Indeed, Siem, von Oettingen, Mummendey, and Nadler (2013) found that disadvantaged- and advantaged-group members exhibited such divergent needs only when group-based disparity was perceived as illegitimate. To illustrate, in one study (Siem et al., 2013, Study 1) participants were assigned to one of two competing groups whose task was to solve difficult math problems. While in the legitimate condition both groups were not allowed to use calculators, in the illegitimate condition one group (the advantaged group) was allowed to use calculators whereas the other (the disadvantaged group) was not. The group that solved more problems (the advantaged group in the illegitimate condition; one of the groups in the legitimate condition) then won several rewards. In line with assumptions, advantaged-group members showed a heightened need for moral acceptance as compared to disadvantaged-group members, and disadvantaged-group members exhibited a heightened need for power as compared to advantaged-group members, when group disparity was perceived to be illegitimate (stemming from an unfair discrimination) but not when it was perceived as legitimate (reflecting differential abilities).

Notably, consistent with the social identity perspective (Tajfel \& Turner, 1979, 1986), Siem and colleagues' (2013) research conceptualized the legitimacy of group disparity as an consensual characteristic of the social system (see also Jetten et al. 2013). That is, the social system was either legitimate (when the two competing groups had equal conditions) or illegitimate (when one group was given an advantage over the other). Yet, within the same social system, individual group members differ in the extent to which they perceive group-based disparities as legitimate: whereas some group members see group-based disparities as unjust, others minimize or legitimize them (Leach, Snider, \& Iyer, 2002). System justification is a construct that may capture these individual differences. 


\section{System Justification Moderates Power- and Morality-Related Needs}

System Justification Theory assumes a general system justification motive, which has been found to reduce moral outrage about group-based disparities, leading both advantaged(Wakslak, Jost, Tyler, \& Chen, 2007) and disadvantaged-group members (Jost \& van der Toorn, 2012) to resist change towards equality. System justification theory's distinctive prediction that tendencies to justify the system should be higher among disadvantaged than advantaged groups (status-legitimacy hypothesis) has been criticized for theoretical inconsistence (Owuamalam, Rubin, \& Spears, 2018) and was disconfirmed in a recent large-scale analysis (Brandt, 2013). However, this assumption is not critical for our argument that individual differences in system justification predict power and morality needs. Whether or not there are mean differences in system justification between advantaged and disadvantaged groups, in both groups there will be people who strive for change towards equality and others who deny the system's drawbacks (Jost \& van der Toorn, 2012).

In addition to the system justification motive, system justification theory assumes, like social identity theory, the existence of a group justification motive; "the tendency to favor members of the ingroup and to disfavor members of other groups with regard to attribution, stereotyping, evaluation, and resource allocation" (Jost, Glaser, Kruglanski, \& Sulloway, 2003, p. 366). Whereas system justification and group justification are positively related for advantaged groups, these motives pull in different directions for disadvantaged groups in that the former would lead them to accept and the latter to challenge their inferior position. Assuming that measures of ingroup identification work as a proxy of the group justification motive, readers might reasonably expect our studies to measure both system justification and ingroup identification ${ }^{4}$. However, our goal was not to test predictions of system

\footnotetext{
${ }^{4}$ Interestingly, previous research among victim and perpetrator groups did not find moderation by identification (Shnabel et al., 2009). This may be due to the multifaceted nature of identification. For example, attachment to one's ingroup's predicts greater group-based guilt, whereas glorification predicts less guilt (Roccas, Klar, \& Liviatan, 2006), and identification with women as a social category is associated with opposing ideologies for traditional vs. feminist women (Cameron \& Lalonde, 2001).
} 
justification theory or social identity theory per se. Rather, we draw on system justification theory as a bridge between the needs-based model, originally formulated to explain reconciliation between victims and perpetrators, and the applied context of structural inequality. The key bridging assumption is that the psychological needs of disadvantaged and advantaged groups will correspond to the needs identified for victims and perpetrators only to the extent that members of these groups view their relative position as illegitimate and would therefore assign blame to their ingroup or to the outgroup. Thus, predictions of the needs-based model should hold true at low levels of system justification. The same cannot, in general, be said about ingroup identification. Although empirically, identification and system justification should be correlated (positively for the advantaged, negatively for the disadvantaged), their theoretical status is distinct and only system justification allows for a complete mapping of the needs of victims and perpetrators onto disadvantaged and advantaged groups. Thus, for present purposes we only consider system justification as an individual differences predictor of power and morality needs.

We hypothesized that the extent to which disadvantaged- and advantaged-group members justify the system would moderate their experience of divergent psychological needs in response to group-based disparities. As for the disadvantaged group, high system justifiers were expected to exhibit relatively low levels of need for power because empowering their ingroup means changing the status quo that they wish to preserve. In contrast, we expected low system justifiers among the disadvantaged group to experience an enhanced need for power (i.e., wish their ingroup to become more dominant).

Predictions for advantaged-group members were somewhat more complex. The needs-based model originally assumed an undifferentiated need to restore morality among perpetrators. Yet, recent research has revealed a more nuanced picture. Specifically, studies conducted on contexts of direct violence revealed that perpetrators' concerns about the ingroup's moral essence (shame due to the ingroup's violation of core moral values) predicted positive outgroup orientations, whereas image concerns (shame due to the 
impairment of the ingroup's moral reputation) were associated with defensiveness and negative outgroup orientations (Allpress, Brown, Giner-Sorolla, Deonna, \& Teroni, 2014). Applying these insights to contexts of structural inequality, advantaged groups might be concerned about their public image rather than their ingroup's moral essence. Building on this distinction, we theorized that the experienced need for morality should be qualitatively different among low and high system justifiers.

To capture the defensive moral motivation (the wish to protect the ingroup's image) aroused by information about inequality, we measured (1) need for a positive moral image, and (2) expected acknowledgement; namely, a wish that the outgroup would admit that the advantaged group is wrongfully accused for being immoral (Saguy, Chernyak-Hai, Andrighetto, \& Bryson, 2013). For the advantaged group, expected acknowledgement reflects a heightened motivation to protect the ingroup's moral image by changing the views of the disadvantaged group about it, i.e., having them acknowledge that they are receiving fair treatment (and hence the system does not need to be changed). We hypothesized that system justification would be positively related to the need to defend the ingroup's moral image, because justifying the system is consistent with legitimizing their ingroup's morality (Jost \& van der Toorn, 2012).

To capture the motivation to restore the ingroup's moral essence, we included two measures. The first was group members' feeling of moral shame due to the privileges enjoyed by their ingroup. Moral shame, which implies accepting blameworthiness, reflects a genuine, non-defensive moral concern (Allpress et al., 2014). However, as a self-focused emotion, moral shame can be dissociated from intentions to benefit the outgroup at the expense of ingroup privileges (Iyer, Schmader, \& Lickel, 2007). Therefore, we included an additional facet of a non-defensive moral motivation, namely group members' wish that their ingroup would act more morally toward the outgroup, even at the expense of giving up privileges (SimanTov-Nachlieli, Shnabel, Aydin, \& Ullrich, 2017). We hypothesized that system justification should be negatively related to the need to restore the ingroup's moral essence. 
This is because advantaged-group members low in system justification should be readier to accept that their ingroup enjoys privileges, calling the system's fairness into question.

\section{The Present Research}

We conducted two studies to examine our hypotheses. Study 1 focused on the relations between LGBTIQ* individuals and (cis-)heterosexuals in Germany and Switzerland. LGBTIQ* individuals have a history of discrimination on the part of (cis-)heterosexuals (Herek \& McLemore, 2013). Despite some change towards greater equality, LGBTIQ* individuals in Germany ${ }^{5}$ and Switzerland still suffer from structural disadvantages. For instance, registered partners, as compared to married (cis-)heterosexual couples, are discriminated against in terms of citizenship rights as well as adoption and assisted procreation rules. Perhaps the most severe human right violation is forced sterilization ${ }^{6}$ as a requirement for gender reassignment in Switzerland (and in 20 other European countries; ECRI, 2014b, 2014a; UN Human Rights Council, 2015). Study 2 focused on the context of gender relations in Israel, in which, as in most of the world's societies, women are disadvantaged compared to men (European Institute for Gender Equality, 2015), having less access to resources in terms of work, money, time, and protection from domestic violence. Data and materials used in the present research can be found at https://osf.io/qgdp4/.

\section{Hypotheses}

The following hypotheses sum up our reasoning:

1) Among disadvantaged-group members (LGBTIQ* individuals/women), we expected need for power to be higher than among advantaged-group members ([cis-]heterosexuals/men). However, need for power should be weaker, the higher their

\footnotetext{
${ }^{5}$ The study was conducted in summer 2015 before the bill for legalization of same-sex marriage passed the Bundestag on June 30th, 2017.

${ }^{6}$ The European Court of Human Rights ruled on April 6th, 2017 that the sterilization requirement is an institutionalized violation of human rights.
} 
system justification tendencies. With regard to the advantaged group, system justification was not expected to be negatively related to need for power; if anything, this relationship could be positive.

2) We expected the need to restore the group's moral essence (i.e., moral shame, wish to act more morally) to be higher among advantaged-group members than among disadvantaged-group members. However, we expected system justification to be negatively related to this need. In contrast, we had no theoretical grounds to expect a relationship between system justification and the need to restore the group's moral essence among disadvantaged-group members.

3) In general, the need to defend the ingroup's moral image (i.e., expected acknowledgement, need for moral image) should be higher among advantaged than among disadvantaged groups. Yet, especially LGBTIQ* individuals might have a strong desire to restore their moral image as their behavior is considered morally deviant by parts of society (Herek \& McLemore, 2013). Thus, we did not have any prediction regarding the overall group-means. However, we expected system justification to be positively related to the need to defend the ingroup's moral image among advantaged-group members. No relationship was expected for disadvantaged-group members. If anything, the relationship might be reversed (lower system justification might predict stronger need to defend the disadvantaged ingroup's moral image, because receiving recognition of its morality can serve as the basis for demanding change towards equality).

\section{Study 1: LGBTIQ* Individuals and (Cis-)Heterosexuals}

\section{Method}

Participants. Based on a priori power analysis (assuming a small effect for the interaction and a power of $80 \%$ ), we aimed for recruiting at least 250 cis-heterosexuals and 
250 LGBTIQ* individuals. A total of 675 German-speaking participants from Germany and Switzerland were recruited online (using social networking sites, snowball sampling, and contacting LGBTIQ* groups) and participated voluntarily.

The sample consisted of 253 (cis-)heterosexuals (heterosexual men/women); $M_{\text {age }}=$ 29.63, $S D_{\text {age }}=10.53$ ) and 422 LGBTIQ* individuals $^{7}$ (234 [cis-]homosexuals, 99 [cis-]bisexuals, 89 others, $M_{\text {age }}=32.33, S D_{\text {age }}=12.54$ ) (see Table 1 for details).

Table 1

Sample Composition (Study 1)

\begin{tabular}{lrrr}
\hline Sexual Orientation / Gender & Male & Female & Other \\
\hline (1) Heterosexual & 100 & 153 & 2 \\
(2) Bisexual & 35 & 64 & 4 \\
(3) Homosexual & 115 & 119 & 8 \\
(4) Other & 10 & 44 & 21 \\
\hline
\end{tabular}

Procedure. Participants, who volunteered to take part in an online study about "the relationship between heterosexuals and LGBTIQ* individuals" first completed demographic information and the measure of system justification. Next, participants were confronted with a paragraph about the existing group-based disparities in the LGBTIQ* context:

"Even though the Swiss/German society has the ideal of a tolerant society, various domains exist in which LGBTIQ* individuals are discriminated against. The unequal treatment of same-sex partnerships is, despite important steps towards the implementation of the principle of equal treatment, still a problem - e.g. the adoption law, marriage, or the protection from discrimination."

As a response to this statement, participants completed the measures of their power-

\footnotetext{
${ }^{7}$ Cis-heterosexuals are female and male heterosexuals whose gender (identity) matches the sex they were assigned at birth. We refer to all other participants as LGBTIQ* individuals.
} 
and morality-related needs. Upon completion, participants were thanked and debriefed.

Measures. All items were assessed using 7-point-Likert scales ( $1=$ I strongly disagree, $7=$ I strongly agree).

System justification. We adapted the 8-item system justification scale (Jost \& Kay, 2005) to the LGBTIQ* context (e.g., "Everyone, heterosexuals or homosexuals, have a fair shot at wealth and happiness"). We chose a broader definition for participants who were not cis-heterosexual or cis-homosexual (e.g., "Everyone, heterosexuals or LGBTIQ* people, have a fair shot at wealth and happiness"). In light of the results of the Confirmatory Factor Analysis reported below, we omitted the 2 reverse-coded items ${ }^{8}$, obtaining Cronbach's $\alpha=$ 0.82.

Need for power. Adapted from SimanTov-Nachlieli and Shnabel (2014), four items assessed participants' need for power (e.g., "We should do everything possible to increase the influence of [participant's ingroup] on the state's decision making and legislation"); $\alpha=0.95$.

Moral shame. Three items measured participants' sense of moral shame (e.g., "I sometimes feel ashamed because as [participant's ingroup] our group enjoys privileges that [participant's outgroup] don't"); $\alpha=0.95$.

Act more morally. Adjusted from SimanTov-Nachlieli, Shnabel, and Halabi (2016), three items measured participants' wish that their ingroup would behave more morally, even at the cost of giving up privileges (e.g., "In order to give [participant's outgroup] equal treatment [participant's ingroup] should be ready to pay a certain price if needed"); $\alpha=0.86$.

Expected acknowledgement. Three items measured participants' expectation that the outgroup should acknowledge that their ingroup is moral (e.g., "[Participant's outgroup] should acknowledge that they get totally fair treatment from [participant's ingroup] in

\footnotetext{
${ }^{8}$ Running the regression with a system justification scale based on all items leaves our conclusions intact. The pattern of significant and non-significant results was the same with one exception. For Study 2, moderator analysis indicated that women and men significantly differed on wish to act more morally $\left(b_{\text {act-more-morally }}=\right.$ $-.72, p=.035,95 \%$ : $[-1.40,-0.05])$ when including the reversed-coded items, whereas we found a marginal effect when excluding the reserved-coded items.
} 
Switzerland/Germany"); $\alpha=0.90$. This measure is similar to the measure of "feeling wronged" (e.g., "People from my ingroup are often being accused of racism with no good reason") developed by Saguy et al. (2013). Yet whereas their scale focuses on "the experience of feeling unfairly accused for harboring racial or ethnic biases" (p. 292), our measure focuses on the reputational motivation stemming from this experience, namely the wish that outgroup members' would admit that there is no reason to accuse the ingroup of being immoral.

Need for moral image. Modeled after the measure used in previous research (Shnabel \& Nadler, 2008), four items measured participants' need for positive moral image (e.g., "It is very important for me that [participant's outgroup] will perceive us as moral"); $\alpha=0.88$.

\section{Results $^{9}$}

Confirmatory Factor Analysis. Considering that our scales were adapted or newly constructed, we first ran confirmatory factor analyses (CFA) to assess the viability of assigning items to scales as planned. To evaluate the goodness of fit of our 6-factor model without cross-loadings and error correlations, we used the following criteria of good fit (Hu \& Bentler, 1999): $X^{2} / d f<3$; RMSEA < .06; SRMR < .08; and CFI > .95.

After removing the 2 reverse-coded items from the system justification scale, we obtained a good fit for both (cis-)heterosexuals $\left(X^{2} / d f=1.63\right.$; RMSEA $=0.05$; SRMR $=$ $0.06 ; \mathrm{NNFI}=0.96 ; \mathrm{CFI}=0.97)$ and LGBTIQ $*$ individuals $\left(X^{2} / d f=1.95 ; \mathrm{RMSEA}=0.05\right.$; $\mathrm{SRMR}=0.05 ; \mathrm{NNFI}=0.95 ; \mathrm{CFI}=0.96)$.

In both groups, the strongest factor correlation was between moral shame and wish that the ingroup would act more morally. Thus, we also assessed the fit of a model in which the items of both scales loaded on a common factor. This model fit was clearly worse for both (cis-)heterosexuals $\left(X^{2} / d f=2.28 ; \mathrm{RMSEA}=0.07 ; \mathrm{SRMR}=0.07 ; \mathrm{NNFI}=0.92 ; \mathrm{CFI}\right.$

\footnotetext{
${ }^{9}$ We used R (Version 3.3.2; R Core Team, 2016) and the R-packages lavaan (Version 0.6.1.1175; Rosseel, 2012), papaja (Version 0.1.0.9655; Aust \& Barth, 2016), and psych (Version 1.7.8; Revelle, 2016) for our analyses.
} 
Table 2

Means (SDs) and Correlations (Study 1)

\begin{tabular}{llllllllll}
\hline Variable & Heterosex. & LGBTIQ & $(1)$ & $(2)$ & $(3)$ & $(4)$ & $(5)$ & $(6)$ \\
\hline (1) System Justification & $3.78(1.19)$ & $3.26(1.10)$ & 1.00 & 0.12 & $-0.30^{* * *}$ & $-0.23^{* *}$ & $0.39^{* * *}$ & 0.17 \\
(2) Need for Power & $2.31(1.60)$ & $5.48(1.21)$ & $-0.28^{* * *}$ & 1.00 & -0.16 & $-0.35^{* * *}$ & $0.35^{* * *}$ & 0.09 \\
(3) Moral Shame & $4.49(1.78)$ & $2.42(1.46)$ & $0.24^{* * *}$ & -0.01 & 1.00 & $0.62^{* * *}$ & -0.14 & $0.25^{* * *}$ \\
(4) Act More Morally & $5.68(1.30)$ & $3.60(1.68)$ & $0.24^{* * *}$ & -0.11 & $0.55^{* * *}$ & 1.00 & -0.16 & $0.26^{* * *}$ \\
(5) Exp. Acknowledgment & $4.14(1.78)$ & $5.45(1.47)$ & 0.01 & $0.41^{* * *}$ & 0.08 & $0.16^{* *}$ & 1.00 & $0.43^{* * *}$ \\
(6) Need for Moral Image & $4.80(1.65)$ & $5.71(1.46)$ & $0.16^{* *}$ & 0.11 & $0.18^{* *}$ & $0.30^{* * *}$ & $0.38^{* * *}$ & 1.00 \\
\hline
\end{tabular}

Note. The lower (upper) triangle shows correlations among LGBTIQ* (cis-heterosexual) participants.

$* * * \mathrm{p}<.001, * * \mathrm{p}<.01, * \mathrm{p}<.05$

$=0.93)$ and LGBTIQ $^{*}$ individuals $\left(X^{2} / d f=2.65 ; \mathrm{RMSEA}=0.06 ; \mathrm{SRMR}=0.05 ; \mathrm{NNFI}=\right.$ 0.91; CFI = 0.92). In summary, the CFA indicated support for the assumption of 6 unidimensional constructs so we proceeded by averaging the items to obtain scale scores.

Hypothesis Tests. Preliminary analyses revealed that the results were similar for the different LGBTIQ* subgroups ([cis-]homosexual, [cis-]bisexual, transgender/intersex individuals). Thus, we present the results for all LGBTIQ* individuals together.

According to Hypothesis 1, need for power should be stronger among LGBTIQ* individuals and more strongly negatively predicted by system justification compared with (cis-)heterosexuals. The means and correlations shown in Table 2 are consistent with this hypothesis. The effect size of the difference in need for power between LGBTIQ* individuals and (cis-)heterosexuals was very large, Cohen's $d=2.32, p=<.001,95 \%$ CI: [2.12, 2.52]. Figure 1 shows scatterplots and regression lines with $95 \%$ confidence bands for the relationship between system justification and need for power.

Consistent with Hypothesis 1, system justification and need for power were negatively related among LGBTIQ* individuals $(b=-0.30, p=<.001,95 \%$ CI: $[-0.41,-0.20])$, but slightly positively related among (cis-)heterosexuals $(b=0.16, p=.060,95 \%$ CI: $[-0.01$, 0.33]). Moderated multiple regression analyses indicated that the difference between these 
LGBTIQ*

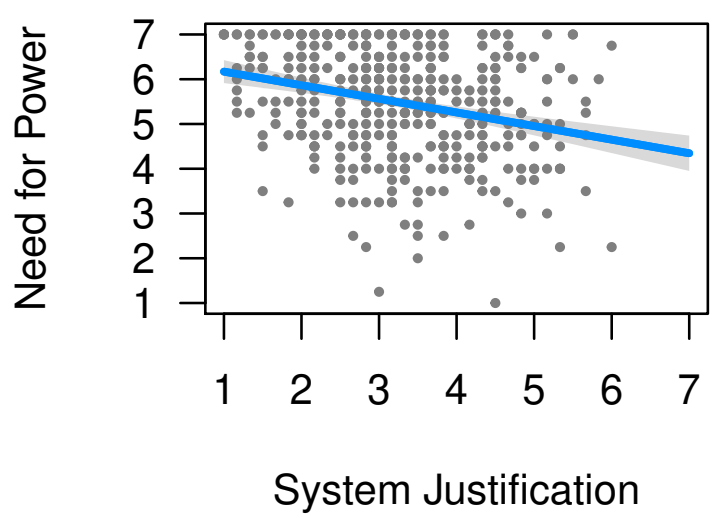

(Cis-)Heterosexuals

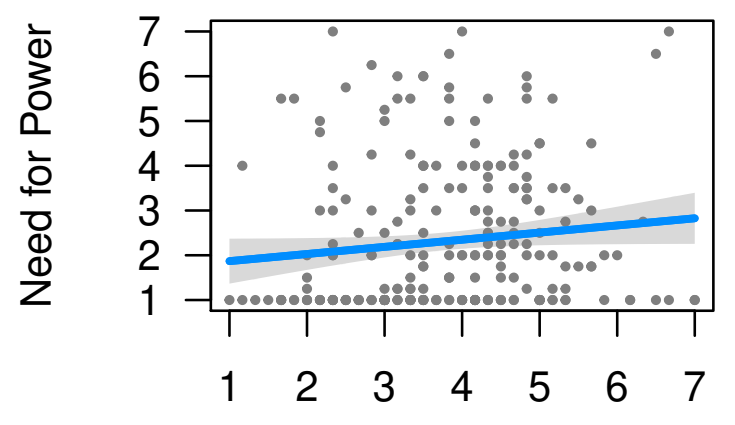

System Justification

Figure 1. Relationship between System Justification and Need for Power (Study 1)

coefficients was significant $(b=-0.46, p=<.001,95 \% \mathrm{CI}:[-0.65,-0.28])$.

According to Hypothesis 2, (cis-)heterosexuals were expected to score higher on the constructs reflecting their need to restore their ingroup's moral-essence (i.e., moral shame and wish to act more morally). Moreover, their system justification tendencies should be more strongly negatively related to these constructs compared with LGBTIQ* individuals.

Results were consistent with this hypothesis. More specifically, (cis-)heterosexuals expressed greater moral shame than LGBTIQ* individuals (Cohen's $d=1.30, p=<.001$, 95\% CI: $[1.13,1.47]$ ) and a greater wish to act more morally (Cohen's $d=1.34, p=<.001$, 95\% CI: $[1.17,1.51])$. Furthermore, as can be seen in Figure 2, system justification was indeed more strongly negatively related to these variables among (cis-)heterosexuals $\left(b_{\text {moral-shame }}=-0.45, p=<.001,95 \%\right.$ CI: $[-0.63,-0.27] ; b_{\text {act-more-morally }}=-0.25, p=<.001$, 95\% CI: $[-0.38,-0.12])$ than among LGBTIQ* individuals, for whom we found positive relationships $\left(b_{\text {moral-shame }}=0.30, p=<.001,95 \%\right.$ CI: $[0.18,0.43] ; b_{\text {act-more-morally }}=0.37, p=$ $<.001,95 \%$ CI: $[0.23,0.51])$. Moderator analyses indicated that the differences between these coefficients were significant $\left(b_{\text {moral-shame }}=0.75, p=<.001,95 \%\right.$ CI: $[0.55,0.96]$; $\left.b_{\text {act-more-morally }}=0.62, p=<.001,95 \% \mathrm{CI}:[0.42,0.82]\right)$.

Next we analyzed the need to defend the ingroup's moral image. Consistent with the 
(Cis-)heterosexuals

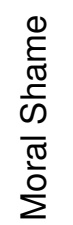

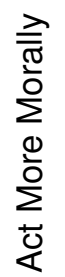

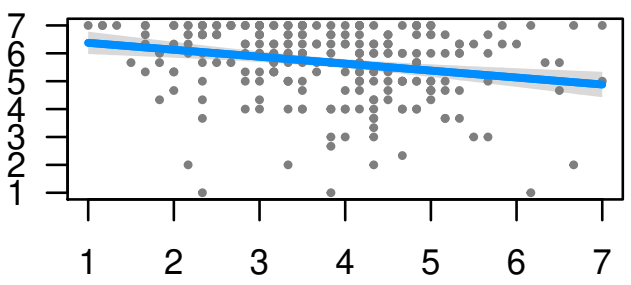

System Justification
LGBTIQ*

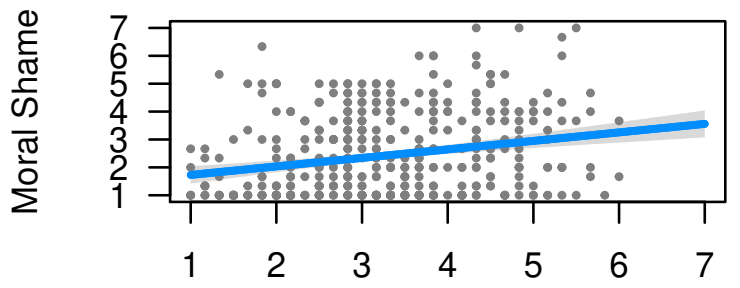

System Justification

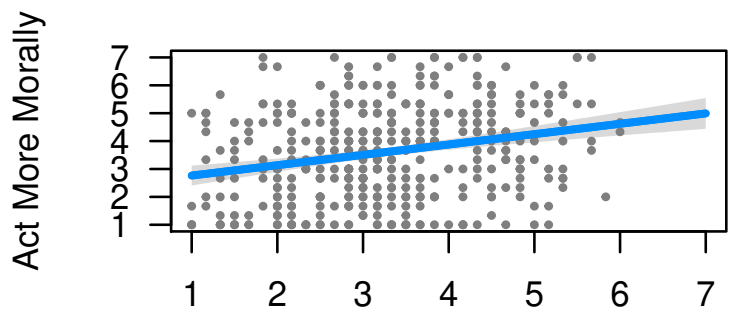

System Justification

Figure 2. Relationship between System Justification and Facets of the Need for Restoration of Moral Essence (Study 1)

fact that LGBTIQ* individuals are morally stigmatized, but contrary to the general logic of the needs-based model, need for moral image (Cohen's $d=-0.60, p=<.001,95 \%$ CI: [-0.76, -0.44]) and expected acknowledgement (Cohen's $d=-0.82, p=<.001,95 \%$ CI: [-0.98, -0.66]) were higher among LGBTIQ* individuals than among (cis-)heterosexuals. Notably, as predicted by Hypothesis 3, system justification was positively related to these variables among (cis-) heterosexuals $\left(b_{\text {need-for-moral-image }}=0.23, p=.008,95 \%\right.$ CI: $[0.06,0.40]$; $b_{\text {expected-acknowledgment }}=0.58, p=<.001,95 \%$ CI: $\left.[0.41,0.75]\right)$.

As seen in Figure 3, the relationships observed among LGBTIQ* individuals $\left(b_{\text {need-for-moral-image }}=0.20, p=.002,95 \% \mathrm{CI}:[0.07,0.33] ; b_{\text {expected-acknowledgment }}=0.01, p=\right.$ $.006,95 \%$ CI: $[-0.12,0.13])$ were only partially different from the relationships among (cis-)heterosexuals. Moderator analyses indicated that the slope difference was significant for expected acknowledgment $(b=-0.58, p=<.001,95 \%$ CI: $[-0.78,-0.37])$, but it was not 


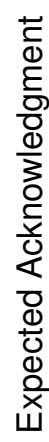

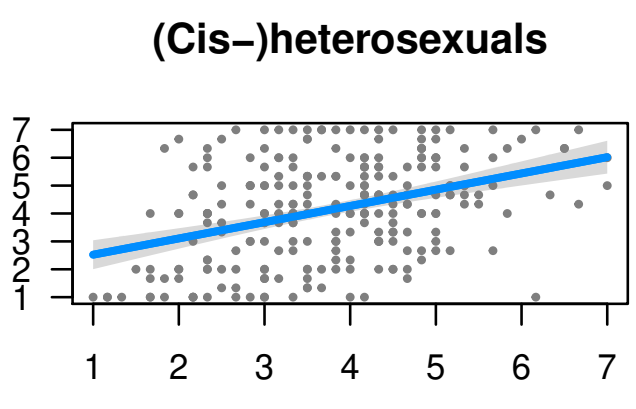

System Justification

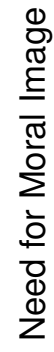

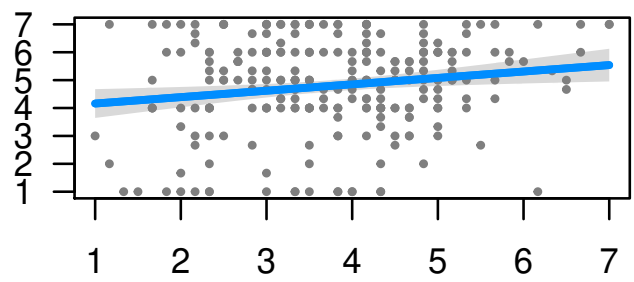

System Justification

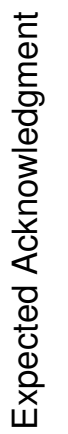

LGBTIQ* $^{\star}$

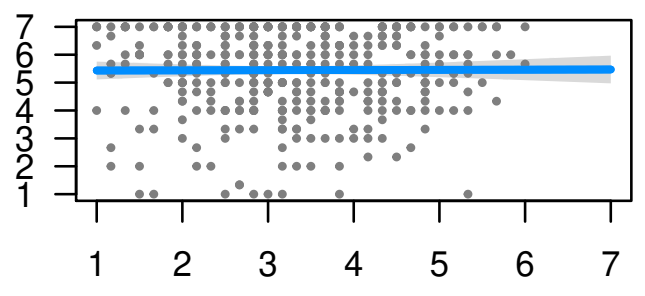

System Justification
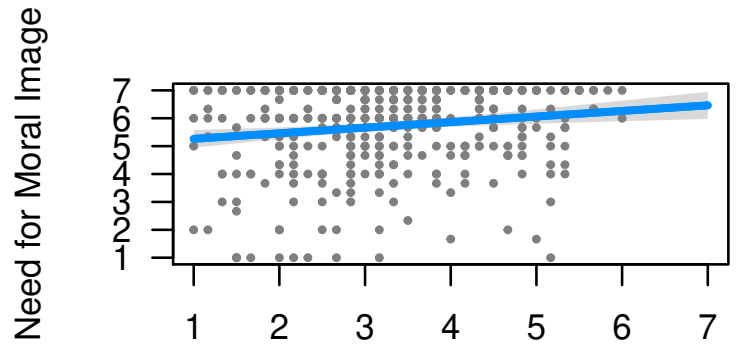

System Justification

Figure 3. Relationship between System Justification and Facets of the Need to Defend the Ingroup's Moral Image (Study 1)

significant for need for moral image $(b=-0.03, p=.777,95 \%$ CI: $[-0.24,0.18])$.

\section{Discussion}

In line with the predictions derived from the needs-based model, LGBTIQ* individuals reported a greater need for power in response to group-based disparities than (cis-)heterosexuals. As expected, system justification was negatively associated with need for power among LGBTIQ* individuals, but slightly positively among (cis-)heterosexuals.

Results for the morality-related needs were also in line with our assumptions.

(Cis-)Heterosexuals reported a greater need to restore the ingroup's moral essence than LGBTIQ* individuals Specifically, they expressed greater moral shame and wish that their ingroup would act more morally towards LGBTIQ* individuals, and this was especially the case the lower their system justification tendencies were. In contrast, among LGBTIQ* 
individuals, higher system justification predicted greater moral shame and wish that their ingroup would act more morally. One possible explanation is that this reflects stigma internalization. Internalized homophobia is a process by which LGBTIQ* individuals come to accept and internalize negative views about their group (Berg, Lemke, \& Ross, 2017). Such homonegativity predicts lower collective action tendencies among LGBTIQ* individuals (Górska, Bilewicz, \& Winiewski, 2017).

Contrary to the needs-based model's logic, LGBTIQ* individuals reported a stronger need to defend the ingroup's moral image than (cis-)heterosexuals. It seems that the unique combination of structural disadvantage and moral stigmatization evokes both power and morality-related needs in LGBTIQ* individuals. This possibility is consistent with the finding that their defensive moral needs were positively related to their need for power and negatively related to their need to restore the group's moral essence (see Table 2). Notably, the associations with system justification tendencies were in line with predictions, such that among (cis-)heterosexuals system justification predicted a stronger need for positive moral image and acknowledgment of their ingroup's morality.

Together, these results highlight that need for morality is more multifaceted than formerly assumed by the needs-based model (e.g., Shnabel et al., 2009). Here we used a more fine-grained conceptualization of morality-related motivations. Specifically, studies conducted on contexts of direct violence (atrocities committed by the British during the Iraq war; Allpress et al., 2014) have revealed different moral threats experienced by members of perpetrator groups, namely, threats to the ingroup's moral essence and threats to the ingroup's reputation (i.e., moral image). The results of Study 1 suggest that these insights can be fruitfully applied to the context of structural inequality between (cis-)heterosexuals and LGBTIQ* individuals 


\section{Study 2: Women and Men}

Study 2 probed into the generalizability of the results to the context of gender inequality. Women in Israel still face structural disadvantages, suffering from poverty, gender-based violence, and inequalities in the labor market (Tzameret-Kertcher, Herzog, \& Chazan, 2016). The gender context is different from that of Study 1 in two major respects: First, whereas stereotypes about LGBTIQ* individuals present them as immoral (e.g., Jayaratne et al., 2006), stereotypes about women portray them as high on morality (Glick \& Fiske, 2001). Second, because men and women are mutually dependent for satisfying their reproductive needs (Guttentag \& Secord, 1983), group interdependence in this particular context is perhaps greater than in any other context of group-based inequality (Glick \& Fiske, 2001). Since group interdependence is associated with perceptions of goal alignment (Esses, Jackson, Dovidio, \& Hodson, 2015) and the motivation to avoid conflict (Jackman, 1994), it might be harder to detect divergence of needs among men and women.

A further goal of Study 2 was to better understand the source of the group differences in the power and morality-related needs. For example, group differences in need for power could result either from an increase in the power-need of disadvantaged-group members in response to information about inequality (the prediction derived from the needs-based model) or a decrease among advantaged-group members (or both). To shed light on this

issue, in Study 2, after exposing all participants to information about inequality (as in Study 1), we asked them to indicate, using bipolar scales with neutral levels represented by their midpoints (see SimanTov-Nachlieli \& Shnabel, 2014, for a similar approach), whether and how reading this information affected their needs. We hypothesized that following the exposure to information about inequality, women would report increased need for power, whereas men would report increased morality-related needs. 


\section{Method}

Participants. We intended to collect as many participants as possible during the academic term. Participants were 154 undergraduate students in Israel who participated in exchange for being included in a raffle of monetary prizes. Ten participants failed the instructional manipulation check (Oppenheimer, Meyvis, \& Davidenko, 2009), which tested whether they had read the experimental instructions. Hence, the final sample included 83 men $\left(M_{\text {age }}=26, S D_{\text {age }}=2.50\right)$ and 61 women $\left(M_{\text {age }}=23, S D_{\text {age }}=1.69\right)$.

Procedure. Participants, who volunteered to take part in an online study about "the relationship between men and women in Israel" first completed demographic information and the measure of system justification. Next, participants were exposed to a text about gender inequality:

"A recent comprehensive study revealed unequivocal evidence showing that the gap between men and women in the Israeli society still exists and even expands. Women generally do not get equal treatment to that of men, and the belief that gender equality has been achieved has no ground in reality."

The text then continued on to review various domains in which women are discriminated against. As a check of text comprehension, participants were asked to indicate the extent to which - according to the text they had read - gender relations in Israel were marked by inequality $(1=$ there is inequality against men, $4=$ there is no gender inequality, $7=$ there is inequality against women).

Finally, participants indicated to which extent the text they had read affected their power and morality-related needs. Upon completion, participants were thanked and debriefed.

Measures. System justification. Participants completed a measure of gender-specific system justification using 7 -point Likert scales $(1=$ not at all, $7=$ very much). Seven items were translated to Hebrew from Jost and Kay's (2005) scale (e.g., "Society is set up so that men and women usually get what they deserve."). As in Study 1, we deleted the 2 
reverse-coded items from the scale. All remaining items were averaged; $\alpha=0.85$.

Finally, participants indicated on 9-point bipolar scales to which extent the text they had read affected $(-4=$ decreased, $0=$ did not change, $+4=$ increased $)$ the following constructs (items were similar to those used in Study 1, with slight adaptations to the present context):

Five constructs measured to which extent the text they had read affected their power and morality-related needs.

Need for power. Four items measured participant's change in the need for power (e.g., "To increase the influence of [participant's ingroup (i.e., men/women)] in the Israeli society"); $\alpha=0.95$.

Moral shame. Three items measured participants' sense of moral shame (e.g., "I sometimes feel ashamed because as [participant's ingroup] our group enjoy privileges that [participant's outgroup] don't"); $\alpha=0.92$.

Act more morally. Three items measured participants' wish that their ingroup would behave more morally (e.g., "We [participant's ingroup] have to change our behavior in order to be more moral towards [participant's outgroup], even if it involves giving up some privileges"); $\alpha=0.78$.

Expected acknowledgment. Three items measured participants' wish that the outgroup would acknowledge that they receive fair treatment from the ingroup (e.g., "[Participant's outgroup] should acknowledge that they receive entirely fair treatment from [participant's ingroup]); $\alpha=0.78$.

Need for moral image. Four items measured participants' need for positive moral image (e.g., "It is very important for me that [participant's outgroup] will perceive us as moral"); $\alpha$ $=0.94$. 
Table 3

Means (SDs) and Correlations (Study 2)

\begin{tabular}{lrrrrrrrr}
\hline Variable & Men & Women & $(1)$ & $(2)$ & $(3)$ & $(4)$ & $(5)$ & $(6)$ \\
\hline (1) System Justification & $4.22(1.09)$ & $3.23(1.01)$ & 1.00 & 0.20 & $-0.40^{* *}$ & $-0.52^{* * *}$ & $0.50^{* * *}$ & $0.35^{* *}$ \\
(2) Need for Power & $-1.84(1.22)$ & $1.21(1.26)$ & -0.30 & 1.00 & $-0.30^{*}$ & $-0.35^{* *}$ & $0.55^{* * *}$ & 0.00 \\
(3) Moral Shame & $1.12(1.45)$ & $-1.85(1.83)$ & 0.00 & -0.13 & 1.00 & $0.65^{* * *}$ & $-0.58^{* * *}$ & 0.01 \\
(4) Act More Morally & $1.28(1.45)$ & $0.53(2.51)$ & -0.08 & 0.30 & -0.28 & 1.00 & $-0.59^{* * *}$ & -0.02 \\
(5) Exp. Acknowledgment & $-0.82(1.68)$ & $0.24(1.12)$ & 0.10 & 0.30 & -0.06 & 0.17 & 1.00 & 0.13 \\
(6) Moral Image & $0.73(1.41)$ & $0.16(1.76)$ & 0.24 & -0.08 & 0.35 & -0.20 & 0.23 & 1.00 \\
\hline
\end{tabular}

Note. The lower (upper) triangle shows correlations among female (male) participants. Values on the dependent variables (variables 2-6) smaller than zero represented decreases, values larger than zero represented increases, and the value zero was equivalent to no change.

*** $\mathrm{p}<.001, * * \mathrm{p}<.01, * \mathrm{p}<.05$

\section{Results}

The comprehension check confirmed that the text was perceived as intended.

Participants' score on the item asking about the extent to which, according to the text, gender relations in Israel were marked by inequality was significantly above four, the scale's neutral midpoint $(M=6.83, S D=0.52$, Cohen's $d=5.50, t(143)=65.96, p=<.001,95 \%$ CI: $[6.75,6.92])$. Table 3 shows descriptive statistics of all other variables.

Hypothesis Tests. Consistent with Hypothesis 1, we found that in response to information about group-disparities women generally reported increased need for power (see Table 3). This value was significantly above the scale's neutral midpoint representing "no change" $(t(60)=7.52, p=<.001,95 \%$ CI: [0.89, 1.53]). By contrast, men reported decreased need for power $(t(81)=-13.64, p=<.001,95 \% \mathrm{CI}:[-2.11,-1.57])$. The effect size of the difference in need for power between women and men was very large (Cohen's $d=$ $2.25, p=<.001,95 \%$ CI: $[1.82,2.67])$. As expected, system justification negatively predicted this reported change in need for power among women $\left(b_{\text {power }}=-0.37, p=.019\right.$, $95 \%$ CI: $[-0.68,-0.06])$, but slightly positively among men $\left(b_{\text {power }}=0.23, p=.069,95 \% \mathrm{CI}\right.$ : $[-0.02,0.47])$. Moderated multiple regression analyses indicated that the difference between 
these coefficients was significant $\left(b_{\text {power }}=0.60, p=.003,95 \%\right.$ CI: $\left.[0.21,0.99]\right)$. The pattern of results was similar to the pattern observed in Study 1. Figure 4 shows scatterplots and regression lines with $95 \%$ confidence bands for the relationship between system justification and need for power.

Women

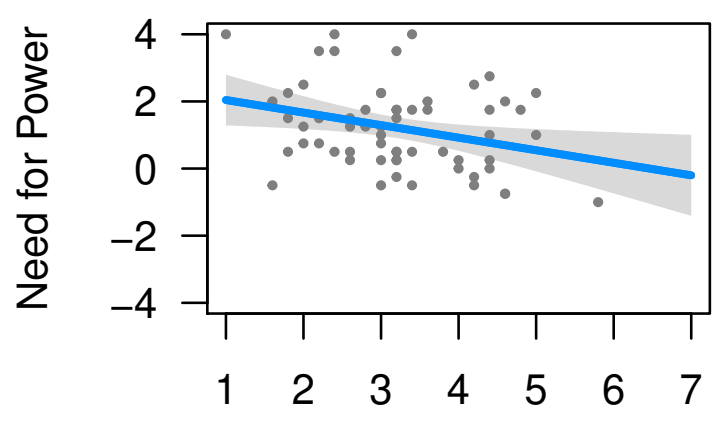

System Justification

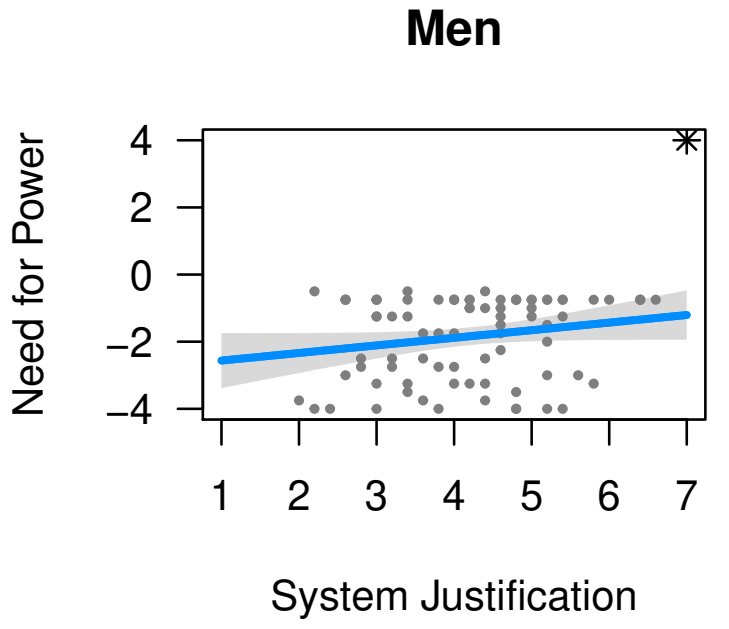

Figure 4. Relationship between System Justification and Need for Power (Study 2). The participant depicted as a star was considered an outlier and not included in the regression analysis.

Regarding the need to restore the ingroup's moral essence, the means and correlations shown in Table 3 are consistent with Hypothesis 2. Specifically, we found that in response to information about group-disparities, men reported increased moral shame and wish to act more morally $(t(82)=6.57, p=<.001,95 \%$ CI: $[0.78,1.45] ; t(82)=7.47, p=<.001,95 \%$ CI: $[0.94,1.62])$.

Men reported stronger increases than women (Cohen's $d_{\text {moral-shame }}=1.78, p=<.001$, 95\% CI: $[1.38 ; 2.16]$; Cohen's $d_{\text {act-more-morally }}=0.37, p=.030,95 \%$ CI: $\left.[0.04,0.70]\right)$. As expected, system justification was negatively related to the increases reported by men $\left(b_{\text {moral-shame }}=-0.63, p=<.001,95 \%\right.$ CI: $[-0.90,-0.36] ; b_{\text {act-more-morally }}=-0.78, p=<.001$, $95 \%$ CI: $[-1.03,-0.53])$, whereas it was unrelated to changes among women $\left(b_{\text {moral-shame }}=\right.$ $-0.01, p=.976,95 \%$ CI: $[-0.48,0.46] ; b_{\text {act-more-morally }}=-0.20, p=.539,95 \%$ CI: $[-0.85,0.45]$; 


\section{Men}

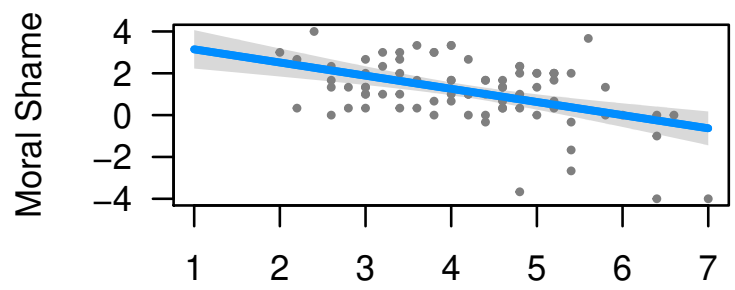

System Justification

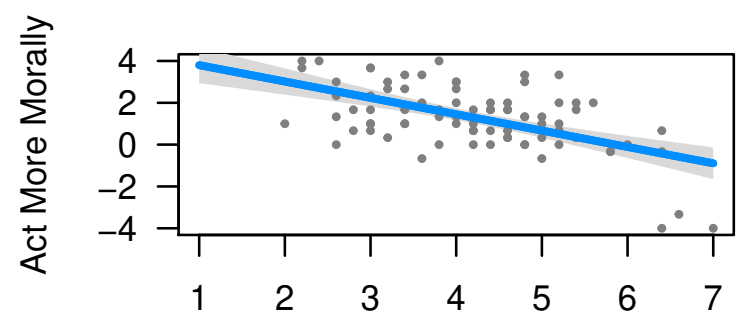

System Justification
Women

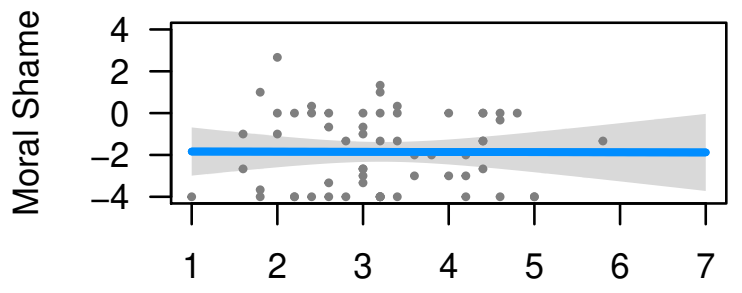

System Justification

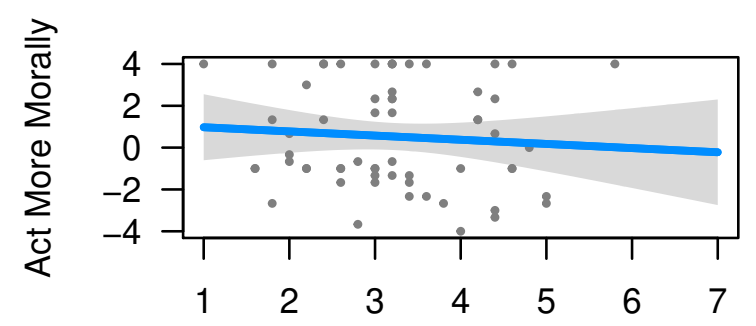

System Justification

Figure 5. Relationship between System Justification and Facets of the Need for Restoration of Moral Essence (Study 2)

see Figure 5). Moderator analyses indicated that the group differences between these coefficients were only significant for moral shame $\left(b_{\text {moral-shame }}=-0.62, p=.017,95 \% \mathrm{CI}\right.$ : $[-1.13,-0.11] ; b_{\text {act-more-morally }}=-0.58, p=.060,95 \%$ CI: $\left.[-1.19,0.03]\right)$.

With regard to the need to defend the ingroup's moral image, the group differences were partly consistent with Study 1. Men reported significant increases in their need for moral image $(p=<.001,95 \% \mathrm{CI}:[0.41,1.04])$, and these increases were greater than among women (Cohen's $d=0.35, p=.037,95 \% \mathrm{CI}$ : [0.02, 0.69]). However, men reported significant decreases in expected acknowledgement $(p=<.001,95 \%$ CI: $[-1.20,-0.44])$, and these decreases were greater than among women (Cohen's $d=-0.70, p=<.001,95 \%$ CI: [-1.04, -0.35]). Consistent with Hypothesis 3, among men, system justification predicted greater reported increases in the need to defend the ingroup's moral image $(b=0.51, p=<.001$, 95\% CI: $[0.25,0.77])$ and smaller reported decreases in expected acknowledgment $(b=0.85$, 


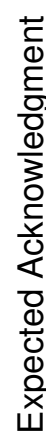

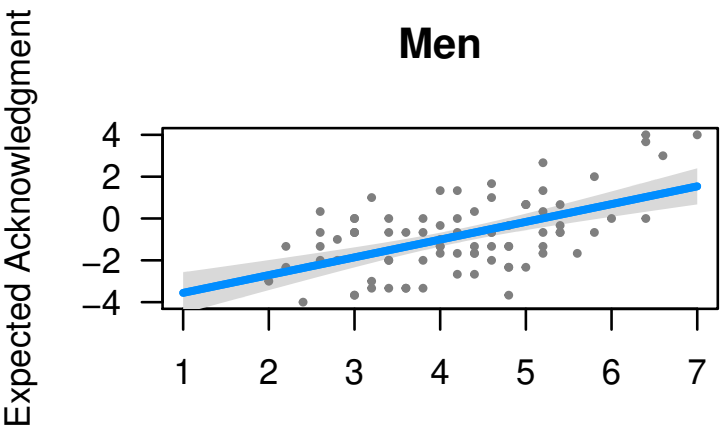

System Justification

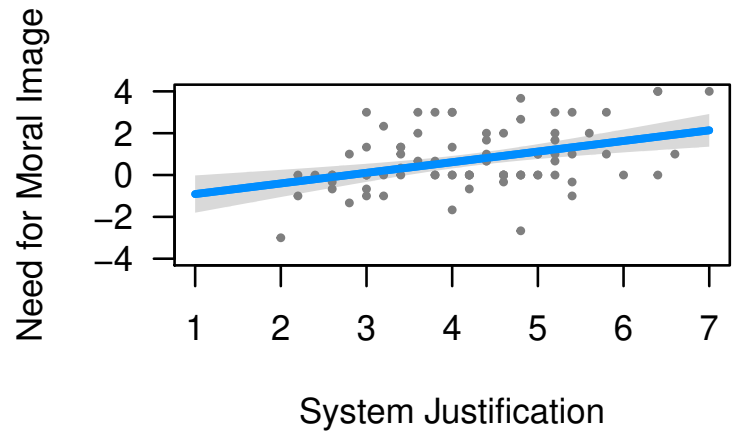

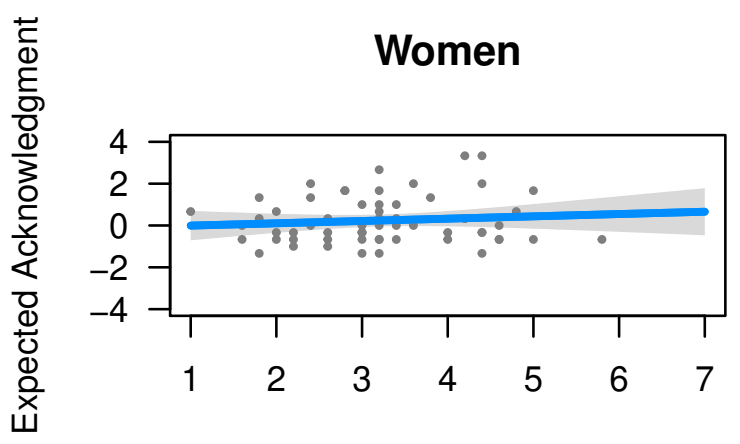

System Justification

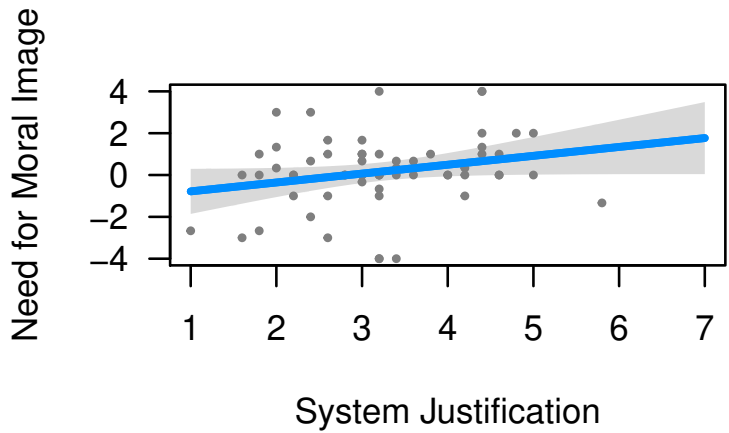

Figure 6. Relationship between System Justification and Facets of the Need to Defend the Ingroup's Moral Image (Study 2)

$p=<.001,95 \% \mathrm{CI}:[0.56,1.14])$, whereas it was not significantly related these variables among women $\left(b_{\text {moral-image }}=0.42, p=.059,95 \% \mathrm{CI}:[-0.02,0.87] ; b_{\text {expected-acknowledgement }}=\right.$ $0.11, p=.446,95 \% \mathrm{CI}:[-0.18,0.40])$. The pattern of relationships shown in Figure 6 was similar to the pattern observed in Study 1. Moderated multiple regression analyses indicated that the slope difference was significant for expected acknowledgment $\left(b_{\text {expected-acknowledgement }}\right.$ $=0.74, p=.001,95 \% \mathrm{CI}:[0.31,1.17])$, but it was not significant for need for moral image $\left(b_{\text {moral-image }}=0.08, p=.733,95 \%\right.$ CI: $\left.[-0.40,0.99]\right)$.

\section{Discussion}

Study 2 generally replicated the results from Study 1 in the context of gender inequality. In line with the needs-based model, women reported an increased need for power in response to information about gender inequality. The lower their system justification, the 
stronger were the increases they reported. Opposite to the pattern found among women, men reported a decrease in their need for power, the more strongly so, the lower their system justification. Thus, similar to the pattern observed in Study 1, group differences in need for power were most apparent for those low in system justification.

Results for the need to restore the ingroup's moral essence are aligned with predictions. Both for moral shame and wish that their ingroup would behave more morally, men reported stronger increases than women. As expected, these increases were greater, the lower their system justification tendencies. In contrast, men reported greater increases in the need to defend the ingroup's moral image (i.e., need for moral image and expected acknowledgment), the higher their system justification tendencies. Thus, the pattern of relationships between system justification and the morality-related needs found among (cis-)heterosexuals in Study 1 was replicated among men in Study 2.

Among women, system justification was unrelated to all morality-related needs. This pattern is different from the one observed among LGBTIQ* individuals, for whom system justification was associated with higher levels of moral shame and wish that the ingroup would behave more morally. A possible interpretation is that this reflects opposite stereotypes pertaining to women's superior (Glick \& Fiske, 2001) vs. LGBTIQ* individuals' inferior (Herek \& McLemore, 2013) moral virtue. Of course, it is important to bear in mind

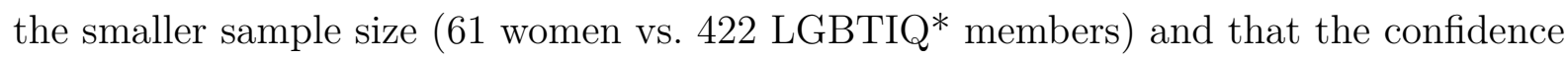
intervals in Study 2 were quite large.

\section{General Discussion}

The present research examined the divergent psychological needs of advantaged(men/cis-heterosexuals) or disadvantaged-group members (women/LGBTIQ* individuals). As the shared history of struggling against social disadvantage would suggest, LGBTIQ* individuals and women expressed a greater need for power in response to information about group-based disparities than advantaged-group members. This need for power was stronger 
among disadvantaged-group members whose system justification was low. This finding is consistent with research showing that system justification predicts less support for collective action (Becker \& Wright, 2011; Calogero, 2013), greater acceptance of sexual violence (Chapleau \& Oswald, 2014), and greater stigma internalization (Bahamondes-Correa, 2016; Pacilli, Taurino, Jost, \& van der Toorn, 2011).

In response to information about group-based disparities, (cis-)heterosexuals and men expressed greater moral shame than disadvantaged-group members and more strongly wished that the ingroup would act more morally, which is consistent with the idea that social privileges can produce a need to restore the ingroup's moral essence (Moscovici \& Pérez, 2009). The need to restore moral essence was stronger among low system justifiers. Thus, consistent with the needs-based model's assumptions (Shnabel \& Ullrich, 2013), the divergence of groups' psychological needs was most pronounced among group members low on system justification. These results replicate and extend Siem et al.'s findings (2013) that the divergence of needs postulated by the needs-based model are contingent on perceived illegitimacy. Whereas legitimacy was manipulated by Siem et al. (2013) in an either-or-fashion, the present research indicates that individual differences in system justification predict the group-specific needs analogously, increasing the generalizability of Siem et al.'s (2013) conclusions.

A second contribution of the present research was to elaborate on the meaning of the need for morality postulated by the needs-based model for advantaged-group members. Building on the distinction between moral essence and image (Allpress et al., 2014), we assumed that high system justifiers being confronted with group-based disparities would desire a positive moral image and expect the outgroup to acknowledge the ingroup's morality, downplaying the need to change their own moral conduct. In contrast, low system justifiers should lack this defensive motivation and experience moral shame and wish that their ingroup would act more morally in the light of group-based disparities. Results supported our assumptions. We found that (cis-)heterosexuals and men low in system justification 
experienced moral shame and wanted to take action on behalf of LGBTIQ* individuals and women. This is consistent with work showing that although advantaged-group members are generally motivated to maintain their dominance (Sidanius \& Pratto, 1999) they may also become vocal and act in solidarity with disadvantaged groups (e.g., Selvanathan, Techakesari, Tropp, \& Barlow, 2017).

In contrast, (cis-)heterosexuals and men high in system justification expressed a motivation to protect their ingroup's moral reputation not through changing the status quo, but by changing the views of the disadvantaged group about it. This finding is consistent with previous work showing moral defensiveness among advantaged-group members, such as engagement in competitive victimhood (attempts to establish that their group is the "true" victim of societal injustice; Sullivan, Landau, Branscombe, \& Rothschild, 2012). Viewed in conjunction with the higher need for power among high system justifiers, the results suggest that these advantaged-group members' heightened wish for acknowledgement reflects a desire to reinforce the existing social arrangement by bestowing moral legitimacy on the ingroup. These findings extend previous work on advantaged-group members' moral defensiveness (e.g., Miron, Branscombe, \& Biernat, 2010) by suggesting that among high system justifiers power-related concerns may be disguised as morality-related concerns.

What does the present research reveal about the specific needs arising from social disadvantage based on gender, gender-identity, and sexual orientation? We found that disadvantaged-group members were on average less prone to system justification than advantaged-group members (which speaks against the status-legitimacy hypothesis, see also Brandt, 2013). Yet, the negative association between system justification and need for power among disadvantaged-group members points to a basic barrier to collective action, because the weakened need for power among high system justifiers may undermine action among LGBTIQ* individuals (Pacilli et al., 2011) and women (Becker \& Wright, 2011) to improve their group's societal position. Conversely, a heightened need for power alone will not necessarily translate into collective action. The goal of the present research was not to predict 
collective action participation and, therefore, did not measure core predictors of collective action. Future research should integrate group-specific needs with established predictors of collective action (e.g., identification, anger, efficacy, moral conviction, van Zomeren, 2013) in attempts to generalize the reported results to actual collective action participation.

Besides experiencing a smaller need for power, LGBTIQ* individuals with high system justification experienced greater moral shame and wish that their ingroup would act more morally towards (cis-)heterosexuals, suggesting that they might link their sexual orientation and/or gender identity to immoral behavior (Herek \& McLemore, 2013; Jayaratne et al., 2006), internalize societies' homonegativity (Berg et al., 2017; Nadal \& Mendoza, 2014), and have lower self-esteem (Lemke, Tornow, \& PlanetRomeo.com, 2015).

On the practical level, it has been argued that to be impactful in their respective social movements, LGBTIQ* individuals and women must mobilize ingroup members but also encourage men and cis-heterosexuals to act in solidarity (Simon \& Klandermans, 2001; Subašić, Reynolds, \& Turner, 2008). Our findings have implications for the planning of effective communication strategies aimed at recruiting people to the cause of social equality. Highlighting existing disparities may be effective if the goal is to recruit individuals low on system justification, who in response to information about inequality express high levels of need for power (disadvantaged-group members) or motivation to improve their ingroup's moral conduct (advantaged-group members). These heightened needs may translate into increased willingness to act for change.

However, if the goal is to recruit high system justifiers, using system-affirmation strategies (Brescoll, Uhlmann, \& Newman, 2013) may be a prerequisite. Such strategies may (at least partially) satisfy high system-justifiers' need to feel that the system is secure (legitimate and stable, Turner \& Brown, 1978), which might reduce their defensiveness. To illustrate, activists may highlight that nowadays, more than in any other historical period, LGBTIQ* individuals or women receive fair treatment, yet some additional changes are required to further fortify the existing system. This type of message, which legitimizes and 
highlights the positive aspects of the existing system rather than merely criticizing it, may be more likely to recruit high system-justifiers than the message that a radical change is required.

In addition, messages aimed at recruiting advantaged-group members high in system justification, who are motivated to defend their ingroup's moral image, can become more effective if they include an affirmation of the advantaged group's morality (see Ditlmann, Purdie-Vaughns, Dovidio, \& Naft, 2017). Understanding the different psychological needs of advantaged- and disadvantaged-group members exposed to information about inequality, and the personal tendencies that shape these needs, can better enable practitioners to structure messages and social environments in ways that increase group members' support for social equality. 


\section{References}

Allpress, J. A., Brown, R., Giner-Sorolla, R., Deonna, J. A., \& Teroni, F. (2014). Two faces of group-based shame. Personality and Social Psychology Bulletin, 40(10), 1270-1284. doi:10.1177/0146167214540724

Aust, F., \& Barth, M. (2016). Papaja: Create apa manuscripts with rmarkdown. Retrieved from https://github.com/crsh/papaja

Bahamondes-Correa, J. (2016). System justification's opposite effects on psychological wellbeing: Testing a moderated mediation model in a gay men and lesbian sample in Chile. Journal of Homosexuality, 63(11), 1537-1555.

doi:10.1080/00918369.2016.1223351

Becker, J. C., \& Wright, S. C. (2011). Yet another dark side of chivalry: Benevolent sexism undermines and hostile sexism motivates collective action for social change. Journal of Personality and Social Psychology, 101(1), 62-77. doi:10.1037/a0022615

Berg, R. C., Lemke, R., \& Ross, M. W. (2017). Sociopolitical and cultural correlates of internalized homonegativity in gay and bisexual men: Findings from a global study. International Journal of Sexual Health, 29(1), 97-111. doi:10.1080/19317611.2016.1247125

Brandt, M. J. (2013). Do the disadvantaged legitimize the social system? A large-scale test of the status-legitimacy hypothesis. Journal of Personality and Social Psychology, 104(5), 765-785. doi:10.1037/a0031751

Brescoll, V. L., Uhlmann, E. L., \& Newman, G. E. (2013). The effects of system-justifying motives on endorsement of essentialist explanations for gender differences. Journal of Personality and Social Psychology, 105(6), 891-908. doi:10.1037/a0034701

Calogero, R. M. (2013). Objects don't object. Psychological Science, 24(3), 312-318. doi:10.1177/0956797612452574

Cameron, J. E., \& Lalonde, R. N. (2001). Social identification and gender-related ideology in women and men. British Journal of Social Psychology, 40(1), 59-77. 
doi:10.1348/014466601164696

Chapleau, K. M., \& Oswald, D. L. (2014). A system justification view of sexual violence: Legitimizing gender inequality and reduced moral outrage are connected to greater rape myth acceptance. Journal of Trauma \& Dissociation, 15(2), 204-218. doi:10.1080/15299732.2014.867573

Ditlmann, Ruth K., Purdie-Vaughns, V., Dovidio, John F., \& Naft, M. J. (2017). The implicit power motive in intergroup dialogues about the history of slavery. Journal of Personality and Social Psychology, 112(1), 116-135. doi:10.1037/pspp0000118.

ECRI. (2014a). ECRI report on germany (fifth monitoring cycle). Strasbourg, France. Retrieved from http://www.coe.int/t/dghl/monitoring/ecri/Country-by-country/ Germany/Germany_CBC_en.asp

ECRI. (2014b). ECRI report on switzerland (fifth monitoring cycle). Strasbourg, France. Retrieved from http://www.coe.int/t/dghl/monitoring/ecri/Country-by-country/ Switzerland/CHE-CbC-V-2014-039-ENG.pdf

Esses, V. M., Jackson, L. M., Dovidio, J. F., \& Hodson, G. (2015). Instrumental relations among groups: Group competition, conflict, and prejudice. In J. F. Dovidio, P. Glick, \& L. A. Rudman (Eds.), On the Nature of Prejudice (pp. 225-243). Wiley-Blackwell. doi:10.1002/9780470773963.ch14

European Institute for Gender Equality. (2015). Gender equality index 2015 - measuring gender equality in the european union 2005-2012: Report. Strasbourg, France.:

Publications Office of the European Union. Retrieved from http://eige.europa.eu/rdc/eige-publications/ gender-equality-index-2015-measuring-gender-equality-european-union-2005-2012-report

Fiske, S. T., Cuddy, A. J., \& Glick, P. (2007). Universal dimensions of social cognition: Warmth and competence. Trends in Cognitive Sciences, 11(2), 77-83. doi:10.1016/j.tics.2006.11.005

Gebhardt, M. (2016). Feminism and lgbt the right to be different. Goethe-Institut. Retrieved 
from https://www.goethe.de/en/kul/ges/20876203.html

Glick, P., \& Fiske, S. T. (2001). An ambivalent alliance: Hostile and benevolent sexism as complementary justifications for gender inequality. American Psychologist, 56(2), 109-118. doi:10.1037/0003-066x.56.2.109

Górska, P., Bilewicz, M., \& Winiewski, M. (2017). Invisible to the state. institutional sexual stigma and collective action of lgb individuals in five east european countries. Group Processes 85 Intergroup Relations, 20, 367-381. doi:10.1177/1368430216684646

Guttentag, M., \& Secord, P. F. (1983). Too many women? The sex ratio question. SAGE Publications.

Hagai, E. B., \& Crosby, F. J. (2016). Between relative deprivation and entitlement: An historical analysis of the battle for same-sex marriage in the united states. In Sabbagh Clara \& M. Schmitt (Eds.), Handbook of social justice theory and research (pp. 477-489). New York, NY: Springer Publishing Co.

Herek, G. M., \& McLemore, K. A. (2013). Sexual prejudice. Annual Review of Psychology, 64(1), 309-333. doi:10.1146/annurev-psych-113011-143826

Herz, M., \& Johansson, T. (2015). The normativity of the concept of heteronormativity. Journal of Homosexuality, 62(8), 1009-1020. doi:10.1080/00918369.2015.1021631

Hu, L., \& Bentler, P. M. (1999). Cutoff criteria for fit indexes in covariance structure analysis: Conventional criteria versus new alternatives. Structural Equation Modeling: A Multidisciplinary Journal, 6, 1-55. doi:10.1080/10705519909540118

Iyer, A., Schmader, T., \& Lickel, B. (2007). Why individuals protest the perceived transgressions of their country. Personality and Social Psychology Bulletin, 33(4), 572-587. doi:10.1177/0146167206297402

Jackman, M. R. (1994). The velvet glove: Paternalism and conflict in gender, class and race relations. University of California Press.

Jayaratne, T. E., Ybarra, O., Sheldon, J. P., Brown, T. N., Feldbaum, M., Pfeffer, C. A., \& Petty, E. M. (2006). White americans' genetic lay theories of race differences and 
sexual orientation: Their relationship with prejudice toward blacks, and gay men and lesbians. Group Processes \& Intergroup Relations, 9(1), 77-94. doi:10.1177/1368430206059863

Jost, J. T., \& Banaji, M. R. (1994). The role of stereotyping in system-justification and the production of false consciousness. British Journal of Social Psychology, 33(1), 1-27. doi:10.1111/j.2044-8309.1994.tb01008.x

Jost, J. T., \& Kay, A. (2005). Exposure to benevolent sexism and complementary gender stereotypes: Consequences for specific and diffuse forms of system justification. Journal of Personality and Social Psychology, 88, 498-509. doi:10.1037/0022-3514.88.3.498

Jost, J. T., \& van der Toorn, J. (2012). System justification theory. In P. A. M. Van Lange, A. W. Kruglanski, \& E. T. Higgins (Eds.), Handbook of theories of social psychology (pp. 313-343). London: Sage Publications.

Jost, J. T., Banaji, M. R., \& Nosek, B. A. (2004). A decade of system justification theory: Accumulated evidence of conscious and unconscious bolstering of the status quo. Political Psychology, 25(6), 881-919. doi:10.1111/j.1467-9221.2004.00402.x

Jost, J. T., Gaucher, D., \& Stern, C. (2015). "The world isn't fair": A system justification perspective on social stratification and inequality. In M. Mikulincer, P. R. Shaver, J. F. Dovidio, \& J. A. Simpson (Eds.), APA handbook of personality and social psychology, volume 2: Group processes. (pp. 317-340). American Psychological Association (APA). doi:10.1037/14342-012

Jost, J. T., Glaser, J., Kruglanski, A. W., \& Sulloway, F. J. (2003). Political conservatism as motivated social cognition. Psychological Bulletin, 129(3), 339-375. doi:10.1037/0033-2909.129.3.339

Killian, L. M. (1985). The stigma of race: Who now bears the mark of cain? Symbolic Interaction, 8(1), 1-14. doi:10.1525/si.1985.8.1.1

Leach, C. W., Snider, N., \& Iyer, A. (2002). "Poisoning the consciences of the fortunate": 
The experience of relative advantage and support for social equality. In I. Walker (Ed.), Relative deprivation: Specification, development, and integration (pp. 136-163). New York, NY: Cambridge University Press.

Lemke, R., Tornow, T., \& PlanetRomeo.com. (2015). Gay happiness monitor — results overview from a global survey on perceived gay-related public opinion and gay well-being. Mainz. Johannes Gutenberg University. Retrieved from https://www.planetromeo.com/wp-content/uploads/2015/05/GAY_HAPPINESS_ MONITOR_2015.pdf

Major, B. (1994). From social inequality to personal entitlement: The role of social comparisons, legitimacy appraisals, and group membership. Advances in Experimental Social Psychology, 293-355. doi:10.1016/s0065-2601(08)60156-2

Martin, K. A. (2009). Normalizing heterosexuality: Mothers' assumptions, talk, and strategies with young children. American Sociological Review, 74(2), 190-207. doi:10.1177/000312240907400202

Miron, A. M., Branscombe, N. R., \& Biernat, M. (2010). Motivated shifting of justice standards. Personality and Social Psychology Bulletin, 36(6), 768-779. doi: $10.1177 / 0146167210370031$

Moscovici, S., \& Pérez, J. A. (2009). A new representation of minorities as victims. In J. M. Butera F. \& Levine (Ed.), Coping with minority status: Responses to exclusion and inclusion. New York: Cambridge University Press.

Nadal, K. L., \& Mendoza, R. J. (2014). Internalized oppression and the lesbian, gay, bisexual, and transgender community. In Internalized oppression: The psychology of marginalized groups. New York, NY: Springer Publishing Co.

Nadler, A., \& Shnabel, N. (2015). Intergroup reconciliation: Instrumental and socio-emotional processes and the needs-based model. European Review of Social Psychology, 26(1), 93-125. doi:10.1080/10463283.2015.1106712

Oppenheimer, D. M., Meyvis, T., \& Davidenko, N. (2009). Instructional manipulation 
checks: Detecting satisficing to increase statistical power. Journal of Experimental Social Psychology, 45(4), 867-872. doi:10.1016/j.jesp.2009.03.009

Owuamalam, C. K., Rubin, M., \& Spears, R. (2018). Addressing evidential and theoretical inconsistencies in system-justification theory with a social identity model of system attitudes. Current Directions in Psychological Science, 0(0), 1-6. doi:10.1177/0963721417737136

Pacilli, M. G., Taurino, A., Jost, J. T., \& van der Toorn, J. (2011). System justification, right-wing conservatism, and internalized homophobia: Gay and lesbian attitudes toward same-sex parenting in Italy. Sex Roles, 65(7-8), 580-595. doi:10.1007/s11199-011-9969-5

Pratto, F., \& Stewart, A. L. (2012). Group dominance and the half-blindness of privilege. Journal of Social Issues, 68(1), 28-45. doi:10.1111/j.1540-4560.2011.01734.x

R Core Team. (2016). R: A language and environment for statistical computing. Vienna, Austria: R Foundation for Statistical Computing. Retrieved from https://www.R-project.org/

Revelle, W. (2016). Psych: Procedures for psychological, psychometric, and personality research. Evanston, Illinois: Northwestern University. Retrieved from https://CRAN.R-project.org/package=psych

Roccas, S., Klar, Y., \& Liviatan, I. (2006). The paradox of group-based guilt: Modes of national identification, conflict vehemence, and reactions to the in-group's moral violations. Journal of Personality and Social Psychology, 91(4), 698-711. doi:doi:10.1037/0022-3514.91.4.698

Rosseel, Y. (2012). lavaan: An R package for structural equation modeling. Journal of Statistical Software, 48(2), 1-36. Retrieved from http://www.jstatsoft.org/v48/i02/

Saguy, T., Chernyak-Hai, L., Andrighetto, L., \& Bryson, J. (2013). When the powerful feels wronged: The legitimization effects of advantaged group members' sense of being accused for harboring racial or ethnic biases. European Journal of Social Psychology, 
43(4), 292-298. doi:10.1002/ejsp.1948

Selvanathan, H. P., Techakesari, P., Tropp, L. R., \& Barlow, F. K. (2017). Whites for racial justice: How contact with black americans predicts support for collective action among white americans. Group Processes 83 Intergroup Relations, 0(0), 1368430217690908. doi:10.1177/1368430217690908

Shnabel, N., \& Nadler, A. (2008). A needs-based model of reconciliation: Satisfying the differential emotional needs of victim and perpetrator as a key to promoting reconciliation. Journal of Personality and Social Psychology, 94(1), 116-132. doi:10.1037/0022-3514.94.1.116

Shnabel, N., \& Ullrich, J. (2013). Increasing intergroup cooperation toward social change by restoring advantaged and disadvantaged groups' positive identities. Journal of Social and Political Psychology, 1, 216-238. doi:10.5964/jspp.v1i1.187

Shnabel, N., Nadler, A., Ullrich, J., Dovidio, J. F., \& Carmi, D. (2009). Promoting reconciliation through the satisfaction of the emotional needs of victimized and perpetrating group members: The needs-based model of reconciliation. Personality and Social Psychology Bulletin, 35(8), 1021-1030. doi:10.1177/0146167209336610

Sidanius, J., \& Pratto, F. (1999). Social dominance: An intergroup theory of social hierarchy and oppression. New York: Cambridge University Press.

Siem, B., von Oettingen, M., Mummendey, A., \& Nadler, A. (2013). When status differences are illegitimate, groups' needs diverge: Testing the needs-based model of reconciliation in contexts of status inequality. European Journal of Social Psychology, 43(2), 137-148. doi:10.1002/ejsp.1929

SimanTov-Nachlieli, I., \& Shnabel, N. (2014). Feeling both victim and perpetrator: Investigating duality within the needs-based model. Personality and Social Psychology Bulletin, 40(3), 301-314. doi:10.1177/0146167213510746

SimanTov-Nachlieli, I., Shnabel, N., \& Halabi, S. (2016). The power to be moral: Affirming israelis' and palestinians' agency promotes prosocial tendencies across group 
boundaries. Journal of Social Issues, 72(3), 566-583. doi:10.1111/josi.12182

SimanTov-Nachlieli, I., Shnabel, N., Aydin, A. L., \& Ullrich, J. (2017). Agents of prosociality: Agency affirmation promotes mutual prosocial tendencies and behavior among conflicting groups. Political Psychology, n/a-n/a. doi:10.1111/pops.12418

Simon, B., \& Klandermans, B. (2001). Politicized collective identity. a social psychological analysis. The American Psychologist, 56(4), 319-331. doi:10.1037/0003-066X.56.4.319

Subašić, E., Reynolds, K. J., \& Turner, J. C. (2008). The political solidarity model of social change: Dynamics of self-categorization in intergroup power relations. Personality and Social Psychology Review, 12(4), 330-352. doi:10.1177/1088868308323223

Sullivan, D., Landau, M. J., Branscombe, N. R., \& Rothschild, Z. K. (2012). Competitive victimhood as a response to accusations of ingroup harm doing. Journal of Personality and Social Psychology, 102(4), 778-795. doi:10.1037/a0026573

Tajfel, H., \& Turner, J. C. (1979). An integrative theory of intergroup conflict. In W. Austin \& S. Worchel (Eds.), The social psychology of intergroup relations (pp. 33-47). Monterey, CA: Brooks/Cole.

Tajfel, H., \& Turner, J. C. (1986). The social identity theory of intergroup behaviour. In S. Worchel \& W. G. Austin (Eds.), The psychology of intergroup relations (pp. 7-24). Chicago, IL: Nelson-Hall.

Turner, J. C., \& Brown, R. (1978). Social status, cognitive alternatives, and intergroup relations. In D. Snow, Soule S.A., \& H. Kriesi (Eds.), Differentiation between social groups (pp. 201-234). London, UK: Academic Press.

Tzameret-Kertcher, H., Herzog, H., \& Chazan, N. (2016). Gender inequality in Israel. 2016. WIPS - The Center for the Advancement of Women in the Public Sphere.

UN Human Rights Council. (2015). Discrimination and violence against individuals based on their sexual orientation and gender identity. Retrieved from http://www.refworld.org/docid/5571577c4.html

van Zomeren, M. (2013). Four core social-Psychological motivations to undertake collective 
action. Social and Personality Psychology Compass, 7(6), 378-388.

doi:10.1111/spc3.12031

Wakslak, C. J., Jost, J. T., Tyler, T. R., \& Chen, E. S. (2007). Moral outrage mediates the dampening effect of system justification on support for redistributive social policies. Psychological Science, 18(3), 267-274. doi:10.1111/j.1467-9280.2007.01887.x

Whittier, N. (2004). The consequences of social movements for each other. In D. Snow, Soule S.A., \& H. Kriesi (Eds.), The Blackwell companion to social movements (pp. 531-551). Oxford, UK: Blackwell Publishing Ltd. 